\title{
Up-Regulation of NAG-1 and p21 Genes by Sulforaphane
}

\author{
Byung-Geol Jeong ${ }^{2}$, Soon Young Kim', Kon Joo Lee ${ }^{1}$ and Jong-Sik Kim* \\ ${ }^{1}$ Department of Biological Sciences, Andong National University, Andong 760-749, Korea \\ ${ }^{2}$ Nensys Inc, Andong 760-380, Korea
}

Received November 17, 2011 /Revised February 14, 2012 /Accepted February 17, 2012

\begin{abstract}
We investigated the anti-proliferative activity of sulforaphane and expression changes of NAG-1 and p21 genes in response to sulforaphane treatment in human colorectal HCT116 cells. The results showed that sulforaphane decreased cell viabilities in a dose-dependent manner and induced expression of NAG-1 and p21 proteins in a dose-dependent and time-dependent manner. In addition, we found that NAG-1 expression by sulforaphane was not dependent on the presence of p53, whereas p21 expression was dependent on p53 presence. The results indicated that up-regulation of NAG-1 was not related with the activity of a dietary histone deacetylase inhibitor of sulforaphane. ATF3 induction was detected from $2 \mathrm{hr}$ after sulforaphane treatment, indicating that ATF3 could be a transcription factor to up-regulate NAG-1 expression. The results of this study may help to increase our understanding of the molecular mechanism of anti-cancer activity mediated by sulforaphane in human colorectal cancer cells.
\end{abstract}

Key words : Sulforaphane, anti-proliferative activity, NAG-1, p21, colorectal cancer cell

\section{서 론}

Sulforaphane은 십자화과 채소에 다량 함유되어 있는 이소 시아네이트(isothiocyanate)의 일종으로서, 특히 브로콜리와 브로콜리 싹에 풍부하다[9]. 지금까지 연구된 sulforaphane의 생리활성은 다양한 세포주 모델에서 항암[15], 항염증[6], 항산 화[19] 활성 등을 중심으로 연구되었다. 이러한 생리활성은 활 성과 관련된 유전자의 발현을 다양한 방법으로 조절함으로써 이루어 진다. 최근 식물유래의 파이토케미칼과 같은 dietary bioactive compounds들이 다양한 epigenetic 조절자로서 유 전자 발현 조절에 영향을 미친다는 총설이 보고된 바 있다 [5,17]. 이러한 파이토케미칼 중 sulforaphane은 dietary histone deacetylase inhibitor로서 암 예방의 활성을 가지는 것으 로 보고되었다[8,10].

NAG-1 (Non-steroidal anti-inflammatory drug-activated gene-1)유전자는 여러 in vitro 모델과 in vivo 모델에서 pro-apoptotic과 anti-tumorigenic 활성이 있는 것으로 보고되 었다 $[4,7,12,22]$. 또한, 여러 종류의 파이토케미칼에 의한 NAG-1 유전자의 발현과 발현조절에 대한 보고가 있었다 $[3,13,18,21]$. 그러나, 파이토케미칼 sulforaphane에 의한 NAG-1 유전자의 발현과 조절에 관한 논문은 전무하다. Cyclin dependent kinase inhibitor의 하나인 p21 유전자는 세 포주기 억제자로 알려져 있다. 최근 Traka 등은 sulforaphane 에 의한 cell cycle arrest가 p21 (WAF1/CIP1) 유전자의 발현

\section{*Corresponding author}

Tel : +82-54-820-5798, Fax : +82-54-820-7705

E-mail : jsk@andong.ac.kr
증가에 의해 이루어 지며, 이러한 p21 유전자의 발현 증가와 전사조절인자인 KLF4 (Kruppel-like factor 4) 유전자의 관련 성에 대해 보고하였다[20].

본 연구에서는 대장암 세포주에서 sulforaphane이 항암유 전자인 NAG-1과 세포주기 억제자인 p21유전자의 발현과 발 현 조절에 관해 연구 하였다. 또한, 이러한 유전자의 발현과 조절에 있어서 sulforaphane이 가지고 있는 dietary histone deacetylase inhibitor의 활성과의 관련성도 검증하였다. 이러 한 연구결과는 sulforaphane에 의한 새로운 항암 활성 기전을 이해하는데 도움을 줄 것으로 기대된다.

\section{재료 및 방법}

\section{세포주 및 파이토케미칼}

대장암 세포주 HCT116 세포주는 American Type Culture Collection (ATCC, USA)에서 구입하였고, p53 null인 HCT116세포주는 Johns Hopkins 의과대학의 Bert Vogelstein 박사로부터 분양 받았다. 세포주 배양은 $10 \%$ FBS (Fetal Bovine Serum, Gibco-BRL, USA), 1\% penicillin 및 streptomycin이 포함된 Dulbecco's Modified Eagle Medium (DMEM, Gibco-BRL, USA)을 사용하였다. 파이토케미칼과 대조구로 사 용된 DMSO (Dimethyl sulfoxide)는 Sigma사(USA)로부터 구 입하여 사용하였다.

Cell viability assay

대장암 세포주 HCT116세포주에서 sulforaphane 처리가 세 
포 성장에 미치는 영향을 연구하기 위해 cell viability assay를 수행하였다. 먼저 96 well plate에 well당 $3 \times 10^{3}$ 개의 세포를 접종하고 24 시간 동안 배양한 후, sulforaphane을 $10,20,30$ $\mu \mathrm{M}$ 의 농도로 처리하였다. 24시간 처리 후 MTS 용액 (Promega, USA)을 각 well 당 $20 \mu 1$ 씩 첨가하고 세포 배양기에 서 4 시간 동안 반응시켰다. 이후 과정은 이전에 보고된 내용과 동일하게 수행하였다[11].

\section{Western blot analysis}

수확한 세포는 RIPA 용액을 첨가하여 sonication을 한 후 총 단백질을 분리하였다. 단백질 정량은 Bradford protein assay 용액(Bio-Rad, USA)을 사용하여 측정하였다. 총 $30 \mu \mathrm{g}$ 의 단백질을 취하여 4 12\% acrylamide gel (Invitrogen, USA)에서 전기영동 한 후, nitrocellulose membrane (Invitrogen, USA)으로 electroblotting 하였다. 이후 Western blot 과정은 이전 보고된 방법과 동일하게 수행하였다[16]. 본 실험에서 사용된 1차 항체로는 anti-NAG1, anti-p21, anti-ATF3 그리고 anti-ACTIN 항체가 사용되었고, 2 차 항체로 는 horseradish peroxidase-conjugated goat anti-rabbit antibody, horseradish peroxidase-conjugated donkey anti-goat 항체를 사용하였다. Anti-NAG-1 항체를 제외한 1차 항체는 Santa Cruz사(USA)로부터 구입하였고, 2차 항체는 Cell Signal사(USA)로부터 구입하였다. NAG-1 항체는 이전에 보 고된 것을 사용하였다[1].

\section{정량적 real-time PCR}

수확한 세포주로부터 total RNA 추출한 다음, total RNA $2 \mu \mathrm{g}$ 을 주형으로, Bio-Rad사(USA)의 iScript cDNA 합성 kit를 이용하여 제조사의 메뉴얼에 따라 $\mathrm{cDNA}$ 를 제조하였다. 합성 된 cDNA $20 \mu \mathrm{l}$ 에 증류수 $40 \mu \mathrm{l}$ 를 첨가하여 희석한 후, real-time PCR의 주형으로 사용하였다. PCR mixture는 Power SYBR $^{\circledR}$ Green PCR Master Mix (Applied Biosystems, USA)를 사용하였으며, 반응 조건은 첫 번째 step으로 $50^{\circ} \mathrm{C}$ 에서 2분, $95^{\circ} \mathrm{C}$ 에서 10 분간 반응시키고, 두 번째 step으로 $95^{\circ} \mathrm{C}$ 에서 15 초, $54^{\circ} \mathrm{C}$ 에서 30 초, $72^{\circ} \mathrm{C}$ 에서 33 초의 cycle을 40 번 반복하여 수행하였다. 결과는 Microsoft Excel을 이용하여 분석, 정량 하였으며, 분석법으로는 comparative Ct (threshold cycle) 방 법을 이용하였다[16].

\section{결과 및 고찰}

\section{Sulforaphane 처리에 의한 대장암 세포 생존율 감소}

브로콜리 유래 파이토케미칼 sulforaphane이 대장암 세포 주 HCT116의 성장에 미치는 영향을 확인하기 위하여 10,20 , $30 \mu \mathrm{M}$ 농도의 sulforaphane을 24시간 동안 처리한 후 세포 생존율 연구를 수행하였다. 그 결과, Fig. 1에서 보는 바와 같

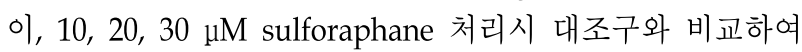
각각 $97.1 \%, 56.2 \%$, 그리고 $40.9 \%$ 의 세포 생존율을 보여 주었 다. 이러한 연구결과는 처리한 sulforaphane 농도 의존적으로 세포 생존율이 감소함을 나타내는 것이다.

Sulforaphane 처리에 의한 NAG-1과 p21 단백질의 발 현 증가

Sulforaphane의 농도별, 시간별 처리에 따른 항암 단백질 NAG-1과 p21의 발현을 확인하였다. 즉, sulforaphane을 10, $20,30 \mu \mathrm{M}$ 농도로 24 시간 동안 처리한 후, 항암 단백질인 NAG-1과 p21 발현을 확인하였다. 그 결과, 두 단백질의 발현 모두 농도 의존적으로 증가하였으며, 각각 $30 \mu \mathrm{M}$ 의 처리군에 서 가장 높은 발현을 보여 주었다(Fig. 2A). 이러한 연구결과는 암 억제유전자인 두 단백질의 발현과 세포 성장 억제와의 밀 접한 관련성을 간접적으로 보여주는 것이다.

또한, sulforaphane의 시간별 처리에 따른 NAG-1과 p21 단백질의 발현을 확인하였다. 즉, $30 \mu \mathrm{M}$ sulforaphane을 0.5 , $1,2,4,6,8,10,24$ 시간 동안 처리한 세포에서 NAG-1과 p21

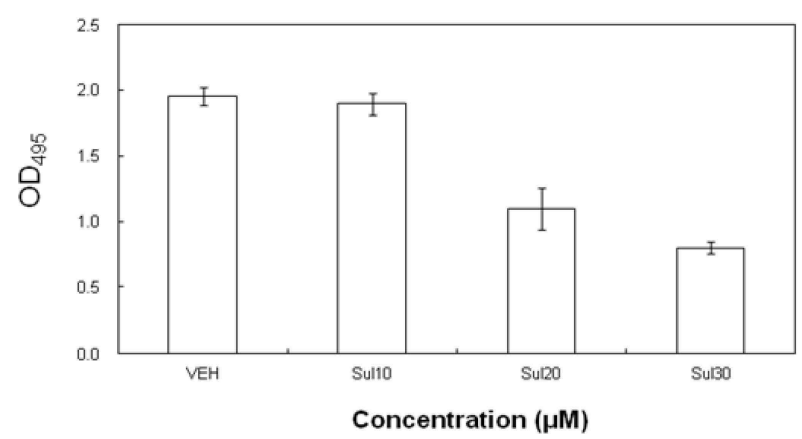

Fig. 1. Effect of sulforaphane on HCT116 cell viability. HCT116 cells were incubated with three different doses of sulforaphane for $24 \mathrm{hr}$. After treatment, cell viability was measured using MTS proliferation assay.

Table 1. Sequences of oligonucleotide primers used for real-time PCR

\begin{tabular}{ccl}
\hline Gene Name & GenBank Acc. No. & \multicolumn{1}{c}{ Sequence } \\
\hline GAPDH & NM_002046 & F: 5'-CTGACCTGCCGTCTAGAAAA-3' \\
& & R: 5'-GAGCTTGACAAAGTGGTCGT-3' \\
\multirow{2}{*}{ NAG-1 } & NM_004864 & F: 5'-CTCTCAGATGCTCCTGGTGT-3' \\
& & R: 5'-GAATATTCCCAGCTCTGGTT-3' \\
\hline
\end{tabular}


A

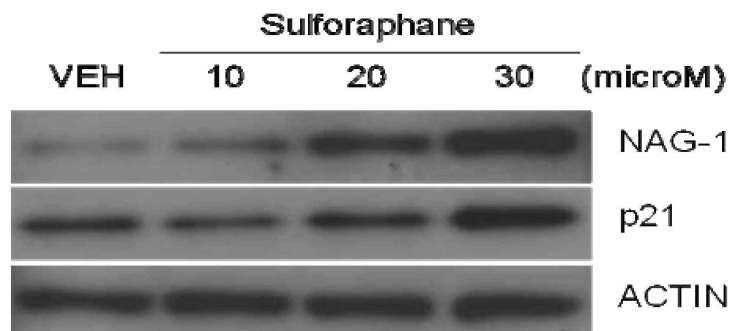

B

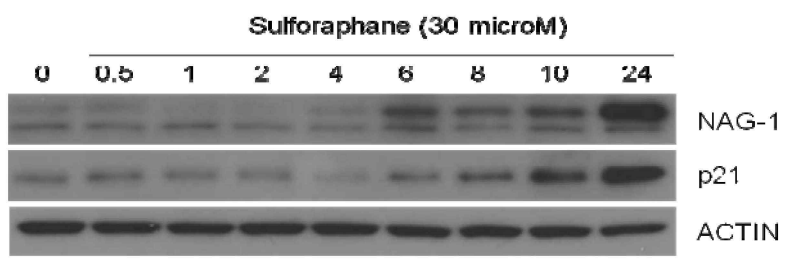

Fig. 2. Expression of NAG-1 and p21 protein by sulforaphane. (A) HCT116 cells were treated with different concentrations of sulforaphane for $24 \mathrm{hr}$. And then, total proteins were prepared from treated cells and used for Western blot analysis. (B) HCT116 cells were treated with $30 \mu \mathrm{M}$ sulforaphane. And treated cells were collected at the different time points. Total proteins were prepared from treated cells and used for Western blot analysis.

단백질 발현을 확인하였다. 그 결과, 두 단백질 모두 6시간 처리군부터 단백질 발현이 확인되었고, 24시간 처리 시 가장 높은 발현을 보여 주었다(Fig. 2B).

따라서, 이러한 연구결과는 sulforaphane에 의한 NAG-1과 p21 단백질의 발현 유도는 농도별, 시간별 의존적으로 일어나 며, 세포사멸과 세포성장 저해와 밀접한 관련이 있는 것으로 생각된다.

파이토케미칼 처리에 의한 NAG-1과 p21 단백질의 발현 증가

Sulforaphane을 포함한 5가지 종류의 파이토케미칼에 의 한 NAG-1과 p21 단백질의 발현을 확인하였다. 그 결과, NAG-1 단백질의 경우 capsaicin (CAP), resveratrol (RES), sulforaphane (SULF)처리에 의한 발현증가가 높았으며, p21 단백질의 경우 capsaicin (CAP), genistein (GEN), sulforaphane (SULF)의 처리에 의해 발현이 높게 증가 되었다 (Fig. 3).

지금까지 sulforaphane을 제외한 파이토케미칼에 의한 NAG-1 단백질의 발현 증가는 본 연구그룹과 다른 연구그룹에 의해 보고된 바 있으나[2,11], sulforaphane에 의한 NAG-1 단 백질의 발현과 조절에 관한 논문은 전무한 실정이다. 따라서, 본 연구에서는 sulforaphane에 의한 NAG-1 단백질 발현과 발현 조절 기전에 대한 연구를 진행하였다.

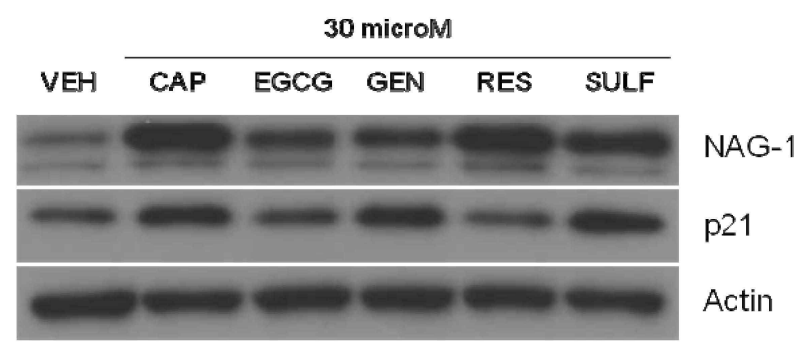

Fig. 3. Expression of NAG-1 and p21 protein by phytochemicals. HCT116 cells were treated with five different kinds of phytochemicals for $24 \mathrm{hr}$. Total proteins were prepared from treated cells and used for Western blot analysis.

A

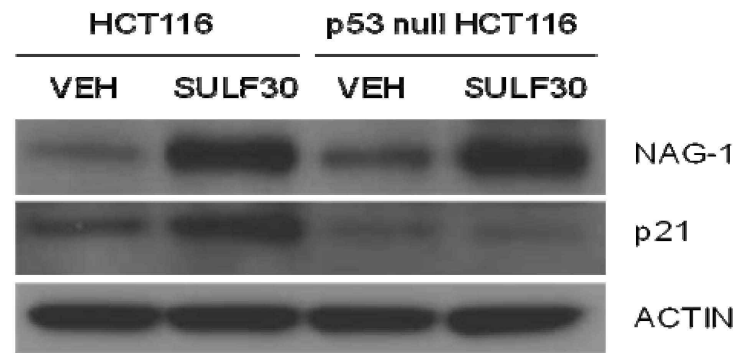

B

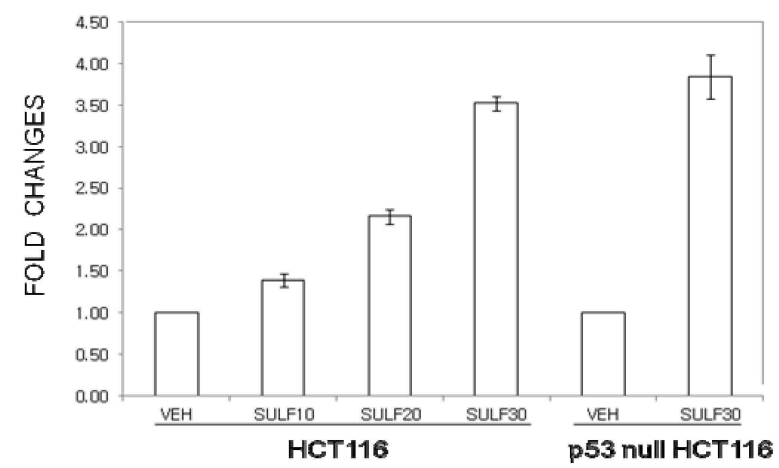

Fig. 4. Effect of p53 on NAG-1 and p21 expression by sulforaphane. (A) HCT116 cells or p53-null HCT116 were treated with $30 \mu \mathrm{M}$ sulforaphane for $24 \mathrm{hr}$ and then Western blot analysis was performed using anti-NAG1, anti-p21, and anti-Actin antibodies. (B) HCT116 cells were treated with three different concentrations of sulforaphane, whereas p53-null HCT116 were incubated with $30 \mu \mathrm{M}$ sulforaphane for $24 \mathrm{hr}$. And then real-time PCR was performed using gene-specific primers.

Sulforaphane에 의한 NAG-1과 p21유전자의 발현 증가 의 $\mathrm{p} 53$ 의존성 검증

파이토케미칼 genistein, resveratrol에 의한 NAG-1 단백질 의 발현은 대표적인 암 억제유전자인 p53에 의해 이루어진다 는 보고가 있었다[2,21]. 따라서, 본 연구에서는 p53 유전자가 null인 HCT116세포주를 이용하여, sulforaphane에 의한 NAG-1의 발현이 p53 의존적인지 확인하였다. 그 결과, Fig. 
$4 \mathrm{~A}$ 에서 보는 바와 같이 NAG-1 단백질의 발현은 정상적인 세포주와 p53이 null인 세포주와 동일하게 이루어지는 것을 확인하였다. 이러한 연구 결과는 sulforaphane에 의한 NAG-1 의 발현은 $\mathrm{p} 53$ 이 아닌, 다른 전사조절인자에 의해 조절된다는 것을 시사한다. 한편, sulforaphane에 의한 p21단백질의 발현 은 p53에 의존적이라는 것을 확인하였다(Fig. $4 \mathrm{~A}$ ).

Sulforaphane처리에 의한 NAG-1의 발현의 p53 의존성을 $\mathrm{mRNA}$ 수준에서 검증하기 위하여, HCT116 세포주에 sulforaphane을 농도별(10, 20, $30 \mu \mathrm{M})$ 로 처리하고, p53 null인 HCT116 세포주에 $30 \mu \mathrm{M}$ sulforaphane을 처리한 후 정량적 $\mathrm{PCR}$ 을 수행하였다. 그 결과, Western blot의 결과와 동일하게, $\mathrm{p} 53$ 이 null인 세포주에서도 NAG-1의 발현이 증가되는 것으 로 확인되어, sulforaphane에 의한 NAG-1의 발현은 p53 비의 존적으로 이루어진다는 것을 재 확인할 수 있었다(Fig. $4 \mathrm{~B})$.

Dietary histone deacetylase inhibitor로서의 NAG-1 단백질의 발현 증가 여부 검증

Sulforaphane은 dietary histone deacetylase inhibitor로서 알려져 있으며, p21과 bax와 같은 항암 유전자의 발현을 유도 함으로서 일부 항암 기능을 가지는 것으로 알려져 있다. 또한, 일부 세포주에서 대표적인 histone deactylase inhibitor인 TSA (Trichostatin A)에 의해 NAG-1 단백질의 발현이 증가된 다는 보고가 있었다[23]. 따라서, 본 연구에서는 TSA를 이용하 여 sulforaphane에 의한 NAG-1의 발현이 sulforaphane이 histone deacetylase inhibitor로서 발현을 증가시키는 것의 여부 를 간접적으로 확인하였다. 그 결과, TSA에 의해서 $\mathrm{p} 21$ 의 발 현은 확실하게 증가하였으나, NAG-1의 발현은 TSA 처리에 의해 매우 미미한 발현 증가를 보여 주었다(Fig. 5). 따라서, sulforaphane에 의한 NAG-1의 발현과 sulforaphane의 histone deacetylase inhibitor로서의 발현과의 관련은 매우 적은 것으로 판단되나, 직접적인 관련성을 증명하기 위해서는 추가 적인 실험이 필요할 것으로 생각된다.

\section{Sulforaphane에 의한 NAG-1 단백질 발현에 있어서} ATF3 유전자의 관련성 검증

일부 파이토케미칼에 의한 NAG-1 단백질의 발현이 전사조 절인자인 ATF3 (Activating Transcription Factor 3)에 의해 이루어 질 수 있다는 연구결과들이 보고되었다[13,14]. 또한, 본 연구그룹의 선행연구 결과에 의하면 $30 \mu \mathrm{M}$ sulforaphane 을 24시간 처리 후 oligo DNA microarray 실험을 한 결과, ATF3 유전자의 발현이 증가됨을 확인하였다(data not shown). 따라서, 본 연구에서는 sulforaphane에 의한 NAG-1 의 발현에 전사조절인자인 ATF3가 관여하는지를 확인하기 위 하여, sulforaphane의 처리에 의해 NAG-1의 발현이 증가되는 것을 확인하였다. 그 결과, Fig. $6 \mathrm{~A}$ 에서 보는 바와 같이, sulforaphane의 농도별 처리에 따른 ATF3 의 발현증가를 확인한

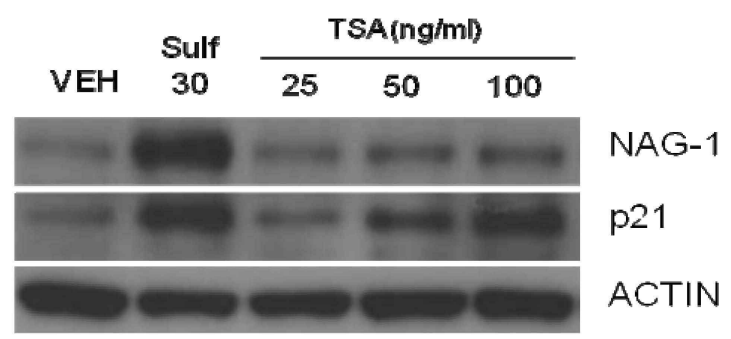

Fig. 5. Expression of NAG-1 protein by sulforapahne and Trichostatin A. HCT116 cells were treated with $30 \mu \mathrm{M}$ suloraphane or three different doses of TSA for $24 \mathrm{hr}$. And then Western blot analysis was performed using anti-NAG1, anti-p21, and anti-Actin antibodies.

A

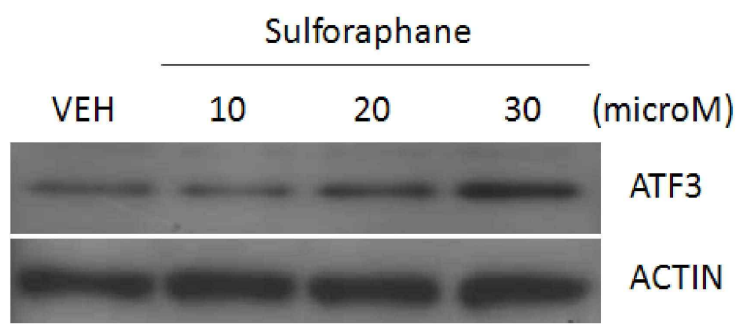

B

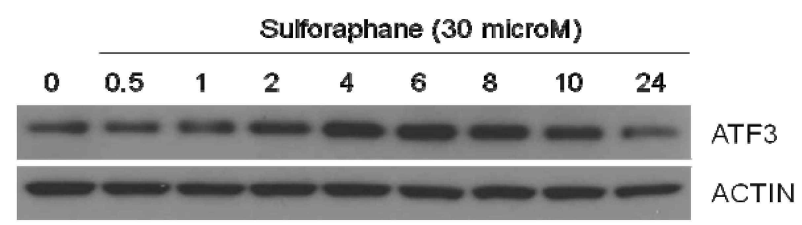

Fig. 6. Expression of ATF3 protein by sulforaphane. (A) HCT116 cells were treated with three different concentrations of sulforaphane for $24 \mathrm{hr}$. And then Western blot analysis was performed using anti-ATF3 and anti-Actin antibodies. (B) HCT116 cells were treated with $30 \mu \mathrm{M}$ of sulforaphane. And then, treated cells were collected at the different time points. Total proteins were prepared from collected cells and used for Western blot analysis.

결과, sulforaphane의 농도 증가에 따라 ATF3의 발현이 증 가됨을 확인하였으나, 발현 증가량은 매우 적었다. 그러나, $30 \mu \mathrm{M}$ sulforaphane을 시간대 별로 처리한 결과, 2시간 처 리 후부터 ATF3 발현이 증가되었다가 10시간 째부터 발현 이 감소됨을 확인하였다(Fig. 6B). 이러한 연구결과를 NAG-1의 발현증가가 6시간째부터 이루어지는 결과(Fig. 2B)와 비교해 보았을 때, sulforaphane에 의한 NAG-1의 발 현증가는 ATF3에 의해 유도되어질 가능성이 매우 높은 것 으로 판단된다. 하지만, 좀 더 정확한 증명을 위해서는 promoter assay나 ATF3- siRNA를 이용한 추가적인 실험이 필 요할 것으로 판단된다. 


\section{References}

1. Baek, S. J., K. S. Kim, J. B. Nixon, L. C. Wilson, and T. E. Eling. 2001. Cyclooxygenase inhibitors regulate the expression of a TGF-beta superfamily member that has proapoptotic and antitumorigenic activities. Mol. Pharmacol. 59, 901-908.

2. Baek, S. J., L. C. Wilson, and T. E. Eling. 2002. Resveratrol enhances the expression of non-steroidal anti-inflammatory drug-activated gene (NAG-1) by increasing the expression of p53. Carcinogenesis 23, 425-434.

3. Baek, S. J., J. S. Kim, F. R. Jackson, T. E. Eling, M. F. McEntee, and S. H. Lee. 2004. Epicatechin gallate-induced expression of NAG-1 is associated with growth inhibition and apoptosis in colon cancer cells. Carcinogenesis 25, 2425-2432.

4. Baek, S. J., R. Okazaki, S. H. Lee, J. Martinez, J. S. Kim, K. Yamaguchi, Y. Mishina, D. W. Martin, A. Shoieb, M. F. McEntee, and T. E. Eling. 2006. Nonsteroidal anti-inflammatory drug-activated gene- 1 over expression in transgenic mice suppresses intestinal neoplasia. Gastroenterology 131, 1553-1560.

5. Berner, C., E. Aumüller, A. Gnauck, M. Nestelberger, A. Just, and A. G. Haslberger. 2010. Epigenetic control of estrogen receptor expression and tumor suppressor genes is modulated by bioactive food compounds. Ann. Nutr. Metab. 57, 183-189.

6. Brandenburg, L. O., M. Kipp, R. Lucius, T. Pufe, and C. J. Wruck. 2010. Sulforaphane suppresses LPS-induced inflammation in primary rat microglia. Inflamm Res. 59, 443-450

7. Cekanova, M., S. H. Lee, R. L. Donnell, M. Sukhthankar, T. E. Eling, S. M. Fischer, and S. J. Baek. 2009. Nonsteroidal anti-inflammatory drug-activated gene- 1 expression inhibits urethane-induced pulmonary tumorigenesis in transgenic mice. Cancer Prev. Res. 2, 450-458.

8. Dashwood, R. H. and E. Ho. 2007. Dietary histone deacetylase inhibitors: from cells to mice to man. Semin. Cancer Biol. 17, 363-369.

9. Fahey, J. W., Y. Zhang, and P. Talalay. 1997. Broccoli sprouts: an exceptionally rich source of inducers of enzymes that protect against chemical carcinogens. Proc. Natl. Acad Sci. USA 94, 10367-10372.

10. Ho, E., J. D. Clarke, and R. H. Dashwood. 2009. Dietary sulforaphane, a histone deacetylase inhibitor for cancer prevention. J. Nutr. 139, 2393-2396.

11. Jang, M. J., H. E. Kim, S. M. Son, M. J. Kim, E. W. Seo, Y. H. Kim, and J. S. Kim. 2009. Over-expression of NSAID activated gene-1 by caffeic acid phenethyl ester. J. Life Sci. 19, 1787-1793.
12. Kim, J. S., S. J. Baek, T. Sali, and T. E. Eling. 2005. The conventional nonsteroidal anti-inflammatory drug sulindac sulfide arrests ovarian cancer cell growth via the expression of NAG-1/MIC-1/GDF-15. Mol. Cancer Ther. 4, 487-493.

13. Lee, S. H., J. S. Kim, K. Yamaguchi, T. E. Eling, and S. J. Baek. 2005. Indole-3-carbinol and 3,3'-diindolylmethane induce expression of NAG-1 in a p53-independent manner. Biochem Biophys. Res. Commun. 328, 63-69.

14. Lee, S. H., K. Yamaguchi, J. S. Kim, T. E. Eling, S. Safe, Y. Park, and S. J. Baek. 2006. Conjugated linoleic acid stimulates an anti-tumorigenic protein NAG-1 in an isomer specific manner. Carcinogenesis 27, 972-981.

15. Li, Y., T. Zhang, H. Korkaya, S. Liu, H. F. Lee, B. Newman, Y. Yu, S. G. Clouthier, S. J. Schwartz, M. S. Wicha, and D. Sun. 2010. Sulforaphane, a dietary component of broccoli/broccoli sprouts, inhibits breast cancer stem cells. Clin. Cancer Res. 16, 2580-2590.

16. Livak, K. J. and T. D. Schmittgen. 2001. Analysis of relative gene expression data using real-time quantitative PCR and the 2(-Delta Delta C(T)) Method. Methods 25, 402-408.

17. Meeran, S. M., A. Ahmed, and T. O. Tollefsbol. 2010. Epigenetic targets of bioactive dietary components for cancer prevention and therapy. Clin. Epigenetics 1, 101-116.

18. Piyanuch, R., M. Sukhthankar, G. Wandee, and S. J. Baek. Berberine, a natural isoquinoline alkaloid, induces NAG-1 and ATF3 expression in human colorectal cancer cells. Cancer Lett. 258, 230-240.

19. Sun, X., L. Mi, J. Liu, L. Song, F. L. Chung, and N. Gan. 2011. Sulforaphane prevents microcystin-LR-induced oxidative damage and apoptosis in BALB/c mice. Toxicol. Appl. Pharmacol. 255, 9-17.

20. Traka, M. H., K. F. Chambers, E. K. Lund, R. A. Goodlad, I. T. Johnson, and R. F. Mithen. 2009. Involvement of KLF4 in sulforaphane- and iberin-mediated induction of p21(waf1/cip1). Nutr. Cancer 61, 137-145.

21. Wilson, L. C., S. J. Baek, A. Call, and T. E. Eling. Nonsteroidal anti-inflammatory drug-activated gene (NAG-1) is induced by genistein through the expression of p53 in colorectal cancer cells. Int. J. Cancer 105, 747-753.

22. Yamaguchi, K., S. H. Lee, T. E. Eling, and S. J. Baek. 2006. A novel peroxisome proliferator-activated receptor gamma ligand, MCC-555, induces apoptosis via posttranscriptional regulation of NAG-1 in colorectal cancer cells. Mol. Cancer Ther. 5, 1352-1361.

23. Yoshioka, H., H. Kamitani, T. Watanabe, and T. E. Eling. 2008. Nonsteroidal anti-inflammatory drug-activated gene (NAG-1/GDF15) expression is increased by the histone deacetylase inhibitor trichostatin A. J. Biol. Chem 283, 3312933137. 
초록 : 브로콜리 유래 sulforaphane에 의한 NAG-1과 p21 유전자의 발현 조절

정병걸 ${ }^{2} \cdot$ 김순영 $^{1} \cdot$ 이건주 ${ }^{1} \cdot$ 김종식 $^{1} *$

( ${ }^{1}$ 국립안동대학교 자연과학대학 생명과학과, ${ }^{2}$ (주) 넨시스)

본 연구에서는 대장암 세포주 모델에서 브로콜리 유래 sulforaphane에 의한 항 성장 활성과 항암 단백질 NAG-1과 p21의 발현 및 발현 조절에 대해서 연구하였다. 그 결과, 처리한 sulforaphane의 농도가 증가됨에 따라 세포사멸이 증가되었고, 세포 생존율은 감소하였다. 또한, sulforaphane에 의한 항암 단백질 NAG-1과 p21의 발 현증가를 농도별, 시간대별로 확인한 결과, 두 단백질 모두 sulforaphane 농도와 처리시간 의존적으로 발현이 증 가됨을 확인하였다. Sulforaphane에 의한 NAG-1과 p21의 발현의 p53 의존성을 연구한 결과, p21의 발현은 p53 에 의존적 이지만 NAG-1의 발현은 p53에 비 의존적인 것으로 생각된다. 또한, sulforaphane이 dietary histone deacetylase inhibitor로서 NAG-1의 발현을 증가시킬 가능성은 매우 미미한 것으로 생각된다. 전사조절인자인 ATF3의 발현을 sulforaphane을 시간대 별로 처리한 후 확인한 결과, 2시간째부터 발현이 증가되어 NAG-1의 발 현 보다 먼저 증가됨을 확인하였다. 이러한 연구 결과는 sulforaphane의 항암 기능을 이해하는 새로운 기전을 제시해 줄 것으로 기대된다. 